\title{
Study on Energy Finance Risk Warning Model --- Based on GABP Algorithm
}

\author{
Xiong Zhong ${ }^{1, ~ a, ~ J i a y i n g ~} \mathrm{Tu}^{2, \mathrm{~b}}$ \\ ${ }^{1}$ Guangzhou International Institute of Finance, Guangzhou University, Guangzhou , 510405PR \\ China \\ ${ }^{2}$ McGill University, Desautels faculty of Management, Canada \\ a,bzhongxiong1218@hotmail.com
}

Keywords: energy finance; risk warning; genetic algorithm; neural network

\begin{abstract}
.
Based on the developing features of the energy finance in our country, this paper designs the warning index system covering the systematic features of energy finance risks, which is BP neural network method based on genetic algorithm optimization; the energy finance risk warning model can provide information on risk recognition and risk warning for government and relevant management departments.
\end{abstract}

\section{Introduction}

During recent years, the energy consumption in our country increases with the speed twice of GDP of that year, indicating that the energy consumption level will keep going up during a relative long time and it is necessary to build an improved energy finance risk warning model with strong adaptation.

\section{Indicator system of energy finance risk warning}

Energy finance is a kind of new finance with the combination of energy and finance; generally speaking, energy finance risk refers to a series of paradoxes, problems and various adjusting measures displacements appearing in the energy finance development caused by objective or subjective reasons. This paper builds the energy fiance warning index system suitable for the energy finance development in our coulntry, which can be seen in Table 1. 
Table 1: Indicator system of energy finance risk warning

\begin{tabular}{|c|c|c|}
\hline First level & Second level & Significance of indicators \\
\hline \multirow{4}{*}{$\begin{array}{l}\text { Index group of } \\
\text { macroeconomy }\end{array}$} & GDP growth rate & $\begin{array}{l}\text { Measuring the quality of macroeconomic } \\
\text { environment }\end{array}$ \\
\hline & GDP deflator & Measuring the inflation level of a country \\
\hline & Exchange rate volatility & Measuring the risk state of finance risk \\
\hline & Shanghai composite index & $\begin{array}{l}\text { Measuring the security market financing of energy } \\
\text { enterprises }\end{array}$ \\
\hline \multirow{2}{*}{$\begin{array}{l}\text { Index group of energy } \\
\text { industry }\end{array}$} & $\begin{array}{l}\text { Price index of commercial } \\
\text { fuel }\end{array}$ & $\begin{array}{l}\text { Measuring the supply and demand state of global } \\
\text { energy }\end{array}$ \\
\hline & $\begin{array}{l}\text { Prosperity index of energy } \\
\text { enterprises }\end{array}$ & $\begin{array}{l}\text { Measuring the entire state of production and } \\
\text { opeartion of energy industries }\end{array}$ \\
\hline \multirow{3}{*}{$\begin{array}{l}\text { Index group of banks } \\
\text { and energy enterprises }\end{array}$} & Interest coverage multiple & $\begin{array}{l}\text { Measuring the interest payment competence of } \\
\text { energy enterprises }\end{array}$ \\
\hline & Non-performing loan ratio & Measuring the debt quality of energy enterprises \\
\hline & Aasset-liability ratio & $\begin{array}{l}\text { Measuring the debt burden state of energy } \\
\text { enterprises }\end{array}$ \\
\hline
\end{tabular}

\section{Study method of energy finance risk}

This paper divides the energy industry into oil and gas mining, coal mining and washing, and power generation industries and uses the neural network GABP algorithm optimized by genetic algorithm to study energy finance risk warning model based on the warning indicator data from WIND database. GABP algorithm is the best warning method at present and also the optimal choice to study energy finance risk warning. There are three reasons: firstly, the energy finance risk warning in our country just starts and relevant data is not complete, while GABP algorithm has strong information processing function; secondly, energy finance risk warning model is a complicated and large system with complex non-linear relations among different factors, while GABP algorithm can deal with plenty of non-linear relations; thirdly, during learning and training, GABP algorithm can recognize the internal relationship between input and output, so as to get rid of the inappropriate part during manual handling data and deal with data objectively.

\section{Regional finance risk indicators selection and research methods}

\section{Regional finance risk indicators}

It is necessary to consider the universality of financial risk factors and the regional feature of fiance development in the selection of regional finance risk indicators, and the phase characteristics of local finance development should be reflected. Principles of selection indicators: firstly, selected indicators hould be as simple as possible and representative; secondly, the availability of data should be considered; thirdly, the selection cost of data and the practicability of model prediction should be balanced. The selected indicators can be seen in Table 2 . 


\begin{tabular}{|c|c|c|}
\hline Indicators & $\begin{array}{l}\text { Varia } \\
\text { ble }\end{array}$ & Economic significance \\
\hline GDP growth rate & $\mathrm{X} 1$ & $\begin{array}{l}\text { If the growth rate is too high, it indicates the economy is overheated and } \\
\text { inflation is easy to take place; if it is too low, it indicates that recession may } \\
\text { occur. }\end{array}$ \\
\hline $\begin{array}{c}\text { Growth rate } \\
\text { fixed-asset investment }\end{array}$ & $\mathrm{X} 2$ & $\begin{array}{l}\text { Decreasing investment is the sign of economic weakness; over-expansion } \\
\text { of investment may cause inflation. }\end{array}$ \\
\hline Export growth rate & X3 & $\begin{array}{l}\text { It reflects the international comopetitiveness of local products, influencing the } \\
\text { foreign countries' demand of domestic currency. }\end{array}$ \\
\hline Inflation rate & $\mathrm{X} 4$ & $\begin{array}{l}\text { It influences the economic growth rate and real growth rate. } \\
\text { Inflation and deflation are not benefitial for the economic } \\
\text { development. }\end{array}$ \\
\hline Industrial structure & $\mathrm{X} 5$ & $\begin{array}{l}\text { It is indicated with the weights of three industries. It reflects the quality and } \\
\text { degree of economic development. }\end{array}$ \\
\hline $\begin{array}{cc}\text { Fiscal } & \text { expenditure } \\
\text { growth rate } & \end{array}$ & $\mathrm{X} 6$ & $\begin{array}{l}\text { It reflects the ability of llocal governemtn finance supporting economy. If } \\
\text { this indivator is too low, it shows the fiscal support is weak; if the indicator is } \\
\text { too high, the fiscal support is non-sustainable. }\end{array}$ \\
\hline $\begin{array}{l}\text { Fiscal revenue / fiscal } \\
\text { expenditure } \quad \text { (fiscal } \\
\text { self-sufficiency degree) }\end{array}$ & $\mathrm{X} 7$ & $\begin{array}{l}\text { It reflects the self-supporting competence of local finance. The higher the } \\
\text { indicator value is, the stronger is the self-supporting competence; the lower the } \\
\text { indicator value is, it is possible to have local debt risk. }\end{array}$ \\
\hline Bank loan growth rate & $\mathrm{X} 8$ & It reflects the support degree of finance on economic development. \\
\hline Bank loan / deposit & X9 & $\begin{array}{l}\text { It reflects the ratio of local loans in bank deposit. The smaller the ratio is, } \\
\text { the more the deposit outflow, which may damages the local economic } \\
\text { development. }\end{array}$ \\
\hline $\begin{array}{r}\text { Housing } \quad \text { price } \\
\text { growth rate }\end{array}$ & $\mathrm{X} 10$ & $\begin{array}{l}\text { Fast increase in housing price will generate property value bubbles and } \\
\text { cause bank financial risks. }\end{array}$ \\
\hline
\end{tabular}

II. Factor analysis

Factor analysis mainly reaches simplified multi-dimensional data through dimension reduction, which means to find out the basic variables (common factors) of relevant representative multidimensional variales. The factor analysis model is as following:

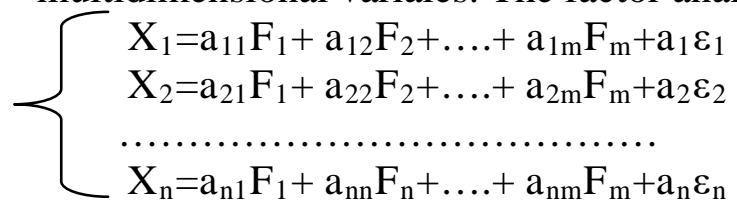

In the formula, multidimensional variables are $X_{1} 、 X_{2} 、 \ldots \ldots . ., X_{n} ; m$ factor variables are $F_{1}$, $\mathrm{F}_{2}, \ldots \ldots . . \mathrm{F}_{\mathrm{n}}, \mathrm{m}<\mathrm{n} ; \varepsilon$ is special factor, which is the part that cannot be explained by factors in original random variables. As for factor analysis, it means to select lesser factors to show more original variables according to certain method, to reach simplification and dimension reduction.

III. Neural network model

Neural network model. Artificial neural network, a model to realize intelligent computation through imitating the working principle of neural network processing outer information.

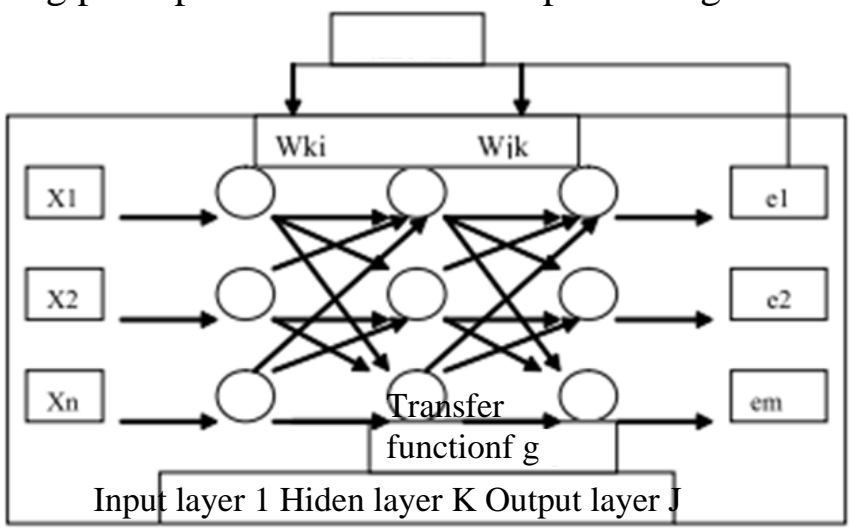

Figure 1 Working principle of BP neural network 
Note: Wki is the weight from input layer to hidden layer; Wjk is the weight from hidden layer to output layer; there are numerous nerve cells in each layer, which are indicated with circles; $\mathrm{f}$ and $\mathrm{g}$ stand for the transfer functions of hidden layer and output layer.

\section{Study on energy finance risk warning model}

Before using BPGA algorith to study energy finance risk warning model, this paper needs to make normalization processing on relevant data.

I. Experimentation of warning model

1. Set weight and valve value of the model. Define the quarter data during 2005-2013 as training sample set, and the quarter data during 2006-2013 as test sample set; import training sample set and test sample set into MATLAB respectively; use NEWFF function to generate a multilayer feedforward BP neural network and adopt following steps to optimize.

(1) Initialize BP neural network. (2) Encode genetic algorithm: $S=R * S 1+S 1 * S 2+S 1+S 2$, where S1 stands for node number in hidden layer, S2 for input node number, R for output node number. (3) Set genetic algorithm parameters: population size is 50, copy operation 0.09 , interlace operation 2 , mutation operation [2 gen 3], genetic algebra 100. (4) Set GABP network fitness function. (5) Assign value for BP neural network.

2. Training and learning neural network

(1) Stipulate training function as TRAINGDX, learning function as LEARNGDM, activation function of hidden layer and output layer as hyperbolic tangent function SIGMOID function. (2) Learning rate is 0.9 , training goal $10 \sim 4$, the largest number of times of training is 104. (3) Training and learning: net input is the normal data of training sample set after normalization processing during 2008-2015, with expected output is the quarter data during 2009-2016.

3. Select nodes of neural network. In the training and learning process of neural network, the number of nodes in hidden layer of network has great influence on network performance; this paper sets the node number in hidden layer of GABP network of energy finance risk warning as 9 .

4. Inspect warning model. Based on above, use the sample data in 2016 to examine the energy finance risk warning GABP network with good performance after training and learning; adopt POSTMNMX function to do anti-normalization on the output data of energy finance risk warning GABP network; if the error absolute value of other index is within 0.2, it indicates that the expected output matches real output well.

Table 3 Test data and model output of finance risk warning of oil and gas

\begin{tabular}{|c|c|c|c|c|c|c|c|c|c|}
\hline & $\begin{array}{l}\text { GDP } \\
\text { growth } \\
\text { rate }\end{array}$ & $\begin{array}{l}\text { GDP } \\
\text { deflato } \\
r\end{array}$ & $\begin{array}{l}\text { Exchan } \\
\text { ge rate } \\
\text { volatilit } \\
\text { y }\end{array}$ & $\begin{array}{l}\text { Shangha } \\
\text { i } \\
\text { composi } \\
\text { te index }\end{array}$ & $\begin{array}{l}\text { Comme } \\
\text { rcial } \\
\text { fuel } \\
\text { price } \\
\text { index }\end{array}$ & $\begin{array}{l}\text { Enterpr } \\
\text { ise } \\
\text { prosper } \\
\text { ity } \\
\text { index }\end{array}$ & $\begin{array}{l}\text { Interest } \\
\text { coverage } \\
\text { ratio }\end{array}$ & $\begin{array}{l}\text { Non-per } \\
\text { forming } \\
\text { loan } \\
\text { ratio }\end{array}$ & $\begin{array}{l}\text { Asset-li } \\
\text { ability } \\
\text { ratio }\end{array}$ \\
\hline \multirow{4}{*}{$\begin{array}{l}\text { Test } \\
\text { input }\end{array}$} & 0.0780 & 0.0230 & 0.8280 & 2.0535 & 1.9455 & 1.6308 & 6.9500 & 6 & 0.0409 \\
\hline & 0.0750 & 0.0205 & 0.8414 & 2.0899 & 1.8460 & 1.6594 & 6.5000 & 0.0096 & 0.0409 \\
\hline & 0.0790 & 0.0210 & 0.8237 & 2.1073 & 1.9571 & 1.6714 & 6.0500 & 0.0097 & 0.0409 \\
\hline & 0.0760 & 0.0222 & 0.8280 & 2.1069 & 1.9206 & 1.5446 & 5.6000 & 0.0100 & 0.0409 \\
\hline \multirow{4}{*}{$\begin{array}{l}\text { Expe } \\
\text { cted } \\
\text { outpu } \\
\text { t } \\
\end{array}$} & 0.0730 & 0.0048 & 0.8272 & 2.1017 & 1.9091 & 1.5210 & 5.4250 & 0.0104 & 0.0409 \\
\hline & 0.0740 & 0.0102 & 0.8343 & 2.1128 & 1.9424 & 1.4910 & 5.2500 & 0.0108 & 0.0409 \\
\hline & 0.0720 & 0.0101 & 0.8496 & 2.1251 & 1.8317 & 1.4000 & 5.0750 & 116 & 0.0409 \\
\hline & 0.0720 & 0.0079 & 0.8499 & 2.1231 & 1.4142 & 1.0710 & 4.9000 & 0.0125 & 0.0409 \\
\hline \multirow{4}{*}{$\begin{array}{l}\text { Real } \\
\text { outpu } \\
t\end{array}$} & 0.0726 & 0.0218 & 0.7659 & 1.8988 & 1.7556 & 1.5080 & 6.4250 & 0.0094 & 0.0383 \\
\hline & 0.0773 & 0.0207 & 0.8733 & 2.1699 & 1.8706 & 1.7228 & 6.7500 & 0.0094 & 0.0419 \\
\hline & 0.0906 & 0.0227 & 0.9617 & 2.4631 & 1.9045 & 1.9532 & 7.0750 & 0.0095 & 0.0460 \\
\hline & 0.0968 & 0.0256 & 1.0910 & 2.7818 & 1.2531 & 2.0384 & 7.4000 & 0.0095 & 0.0504 \\
\hline
\end{tabular}


Table 4 Test data and model output of finance risk warning of coal mining and washing

\begin{tabular}{|c|c|c|c|c|c|c|c|c|c|}
\hline & $\begin{array}{l}\text { GDP } \\
\text { growth } \\
\text { rate }\end{array}$ & $\begin{array}{c}\text { GDP } \\
\text { deflator }\end{array}$ & $\begin{array}{l}\text { Excha } \\
\text { nge } \\
\text { rate } \\
\text { volatili } \\
\text { ty }\end{array}$ & $\begin{array}{l}\text { Shangh } \\
\text { ai } \\
\text { compos } \\
\text { ite } \\
\text { index }\end{array}$ & $\begin{array}{l}\text { Comme } \\
\text { rcial } \\
\text { fuel } \\
\text { price } \\
\text { index }\end{array}$ & $\begin{array}{l}\text { Enterpri } \\
\text { se } \\
\text { prosperi } \\
\text { ty index }\end{array}$ & $\begin{array}{l}\text { Interest } \\
\text { coverag } \\
\text { e ratio }\end{array}$ & $\begin{array}{l}\text { Non-pe } \\
\text { rformin } \\
\text { g loan } \\
\text { ratio }\end{array}$ & $\begin{array}{l}\text { Asset-li } \\
\text { ability } \\
\text { ratio }\end{array}$ \\
\hline \multirow{4}{*}{$\begin{array}{l}\text { Te } \\
\text { st } \\
\text { in } \\
\mathrm{pu} \\
\mathrm{t} \\
\end{array}$} & 0.0780 & 0.0230 & 0.8280 & 2.0535 & 1.9455 & 0.9520 & 3.9750 & 0.0096 & 0.6200 \\
\hline & 0.0750 & 0.0205 & 0.8414 & 2.0899 & 1.8460 & 0.7200 & 3.6500 & 0.0096 & 0.6400 \\
\hline & 0.0790 & 0.0210 & 0.8237 & 2.1073 & 1.9571 & 0.7944 & 3.3250 & 0.0097 & 0.6600 \\
\hline & 0.0760 & 0.0222 & 0.8280 & 2.1069 & 1.9206 & 0.8472 & 3.0000 & 0.0100 & 0.6800 \\
\hline \multirow{4}{*}{$\begin{array}{l}\text { Ex } \\
\text { pe } \\
\text { ct } \\
\text { ed } \\
\text { ou } \\
\text { tp } \\
\text { ut }\end{array}$} & 0.0730 & 0.0048 & 0.8272 & 2.1017 & 1.9091 & 0.7740 & 2.5250 & 0.0104 & 0.6600 \\
\hline & 0.0740 & 0.0102 & 0.8343 & 2.1128 & 1.9424 & 0.7050 & 2.0500 & 0.0108 & 0.6400 \\
\hline & 0.0720 & $\begin{array}{l}0.01 \\
01\end{array}$ & 0.8496 & 2.1251 & 1.8317 & 0.7120 & 1.5750 & 0.0116 & 0.6200 \\
\hline & 0.0720 & 0.0079 & 0.8499 & 2.1231 & 1.4142 & 0.7060 & 1.1000 & 0.0125 & 0.6000 \\
\hline \multirow{4}{*}{$\begin{array}{l}\text { Re } \\
\text { al } \\
\text { ou } \\
\text { tp } \\
\text { ut }\end{array}$} & 0.0716 & 0.0188 & 0.5688 & 2.1717 & 1.2920 & 1.7792 & 2.0250 & 0.0198 & 0.6853 \\
\hline & 0.0737 & 0.0119 & 0.5319 & 2.0881 & 1.2709 & 1.7709 & 2.0500 & 0.0109 & 0.6605 \\
\hline & 0.0728 & 0.0187 & 0.4969 & 2.0515 & 1.2730 & 1.7730 & 2.0750 & 0.0111 & 0.6363 \\
\hline & 0.0815 & 0.0187 & 0.4814 & 2.0095 & 1.2697 & 1.7697 & 2.1000 & 0.0124 & 0.6154 \\
\hline
\end{tabular}

Figure 2 and Figure 3 provide the error curve between expected output and real output of different indicators of oil and gas during four quarters in 2016

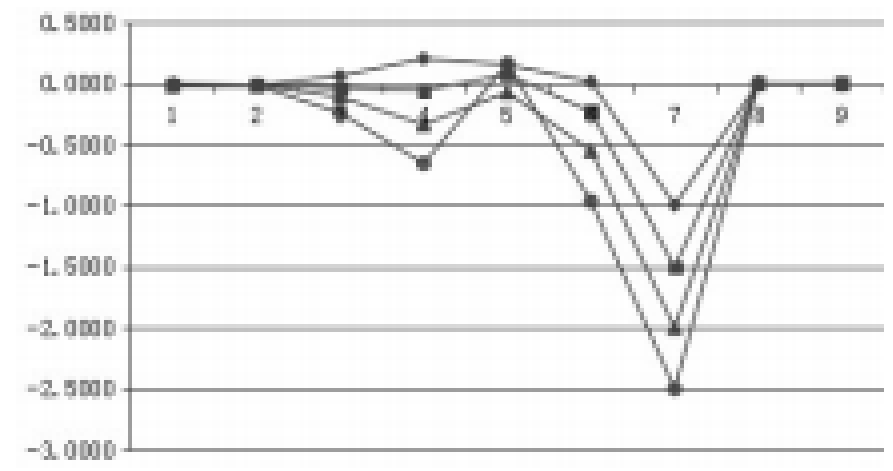

Figure 2 Output error of finance risk warning model of oil and gas in 2016

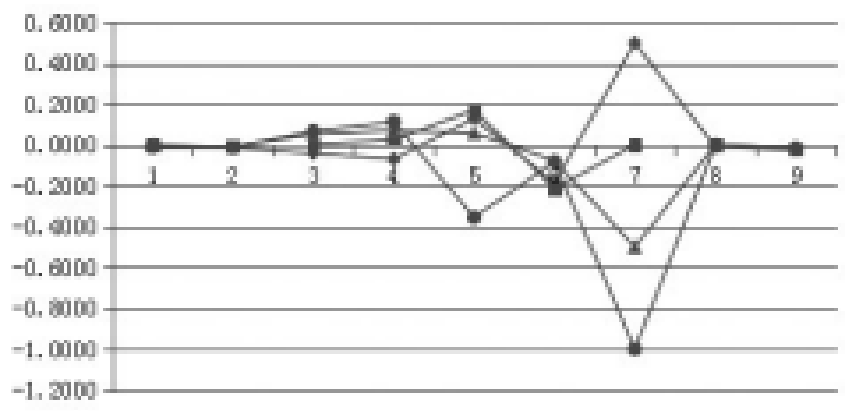


Figure 3 Output error of finance risk warning model of coal mining and washing in 2016 Table 5 Indicator value section of energy finance risk warning

\begin{tabular}{|c|c|c|c|c|c|c|}
\hline $\begin{array}{c}\text { Warning } \\
\text { indicator }\end{array}$ & $\begin{array}{c}\text { Safety } \\
\text { value }\end{array}$ & $\begin{array}{c}\text { Risk } \\
\text { contribut } \\
\text { ion } \\
\text { weight }\end{array}$ & \multicolumn{4}{|c|}{ Indicator section of energy finance risk condition indicator } \\
\hline $\begin{array}{c}\text { GDP growth } \\
\text { rate }\end{array}$ & $6.5 \sim 9.5$ & 0.15 & Safety & Basic safety & Alarm & Unsafety \\
\hline GDP deflator & $2 \sim 5$ & 0.15 & {$[6.5,9.5]$} & {$[5,6.5] \cup[9.5,11]$} & {$[3.5,5 \cup[11,12.5]$} & $\begin{array}{c}{[-100,3.5] \cup} \\
{[12.5,100]}\end{array}$ \\
\hline $\begin{array}{c}\text { Exchange rate } \\
\text { volatility }\end{array}$ & $<3$ & 0.15 & $<3$ & {$[3,5]$} & {$[5,7]$} & $>7$ \\
\hline $\begin{array}{c}\text { Shanghai } \\
\text { composite index }\end{array}$ & $3000 \sim 4500$ & 0.15 & {$[0,1.5]$} & {$[-5,0] \cup[1.5,3]$} & {$[-10,-5] \cup[3,5]$} & $\begin{array}{c}{[-50,-10] \cup} \\
{[5,50]}\end{array}$ \\
\hline $\begin{array}{c}\text { Commercial } \\
\text { fuel price index }\end{array}$ & $150 \sim 200$ & 0.08 & {$[3000,4500]$} & $\begin{array}{c}{[4500,5500] \cup} \\
{[2500,3000]}\end{array}$ & $\begin{array}{c}{[1000,2500] \cup} \\
{[5500,6000]}\end{array}$ & $\begin{array}{c}{[0,1000] \cup} \\
{[6000,+\infty)}\end{array}$ \\
\hline $\begin{array}{c}\text { Enterprise } \\
\text { prosperity index }\end{array}$ & $150 \sim 200$ & 0.08 & $150 \sim 200$ & $100 \sim 150$ & $50 \sim 100$ & $0 \sim 50$ \\
\hline $\begin{array}{c}\text { Interest } \\
\text { coverage ratio }\end{array}$ & 2.5 & 0.08 & $150 \sim 200$ & $100 \sim 150$ & $50 \sim 100$ & $0 \sim 50$ \\
\hline $\begin{array}{c}\text { Non-performing } \\
\text { loan ratio }\end{array}$ & $0 \sim 2$ & 0.08 & $>2.5$ & {$[1,2.5]$} & {$[0.1,1]$} & $<0.1$ \\
\hline $\begin{array}{c}\text { Asset-liability } \\
\text { ratio }\end{array}$ & 6 & 0.08 & $0 \sim 2$ & $2 \sim 5$ & $5 \sim 8$ & $8 \sim 10$ \\
\hline
\end{tabular}

\section{Summary}

The method of energy finance risk warning model is scientific and effective, suitable for the reality of Chinese energy finance development, with strong operability, which can provide information on energy finance risk recognition and risk warning for government and relevant administrative departments.

\section{References}

[1] Su Yufeng. Strategies on Systematic Finance Risks and Macro-prudential Regulation [J]. People's Tribune,2016,(14):80-82.

[2] Wang Xinxia, Lin Xiaoxia. Study on Indicator System of Risk Warming [J]. Western Finance, 2016,(06):83-86+96.

[3] Bao Junchao. Risk on Internet Finance Risk Warning Under Big Data Analysis [J]. Financial Community (Academic Edition),2016,(09):2.

[4] Zhu Zhiheng. Study on Internet Finance Risk Warning Based on BP Neural Network [D]. Xiangtan University, 2016.

[5] Zhang Jie, Gu Lei. Study on Growth Chain Finance Risk and Strategic Solutions [J]. Mudanjiang Normal College Journal (Phylosophy and Social Science),2016,(04):22-25. 